\title{
Keefektifan Model Pembelajaran Kooperatif Tipe Tea Party dalam Keterampilan Berbicara Bahasa Jerman
}

\author{
Riskayanti' dan Wahyu Kurniati Asri \\ Fakultas Bahasa dan Sastra. Universitas Negeri Makassar ${ }^{1,2,}$ \\ E-mail : riskayanti392@gmail.com ${ }^{1}$
}

\section{E-ISSN : 2579-4574}

P-ISSN : 2549-7359

\begin{abstract}
The purpose of this study was to obtain data about the effectiveness of the Tea Party cooperative model in German speaking skills. This research is a quasi-experimental study. Data collection tecnique is speaking skills tests. Data were analyzed using t-test analysis. The results of data analysis show that $t$ count 6.141> $t$ table 1.998 at a significant level of 0.05 . The results showed that the Cooperative Tea Party Type learning model was effectively used in increasing students' German speaking skills.
\end{abstract}

Keywords: Speaking Skills, Tea Party Type

\section{https://ojs.unm.ac.id/eralingua}

\section{PENDAHULUAN}

Pembelajaran bahasa asing telah berkembang di Indonesia seiring dengan kebutuhan masyarakat akan pentingnya kemampuan berbahasa dalam era globalisasi ini. Salah satu bahasa asing yang telah diajarkan di Sekolah Menengah Atas (SMA) yaitu bahasa Jerman. Dalam pembelajaran bahasa Jerman terdapat empat aspek kompetensi berbahasa, salah satunya adalah keterampilan berbicara (sprechen). Untuk dapat menguasai bahasa dengan baik, seseorang harus mengetahui konsep belajar bahasa yang benar, agar para pembelajar dapat menguasai bahasa tersebut dengan baik. Hasil observasi yang dilakukan peneliti di SMAN 1 Kabupaten Bone menunjukkan bahwa sebagian besar siswa mengalami kesulitan dalam berbicara bahasa Jerman, siswa mengalami kesulitan dalam mengungkapkan kata-kata dan kalimat dalam bahasa Jerman. Hal itu disebabkan karena kurangnya latihan berbicara yang diberikan oleh guru. Guru menggunakan metode pembelajaran yang sama dalam setiap penyampaian materi, yaitu dengan menggunakan metode ceramah. Sehingga aktivitas pelatihan terhadap keterampilan berbicara masih kurang.

Berdasarkan hal di atas, diperlukan sebuah model pembelajaran yang dapat meningkatkan kemampuan berbicara mahasiswa. Salah satu model pembelajaran yang bervariasi dan inovatif adalah model pembelajaran kooperatif. Salah satu model pembelajaran yang dapat mengembangkan kemampuan mengungkapkan ide siswa adalah model pembelajaran kooperatif. Pembelajaran kooperatif merupakan strategi pembelajaran dengan sejumlah siswa sebagai anggota kelompok kecil dengan kemampuan yang berbeda-beda. Pengertian model pembelajaran kooperatif dikemukakan oleh Riyanto (2009:267) bahwa 
pembelajaran kooperatif adalah model pembelajaran yang dimaksudkan untuk membelajarkan kecakapan akademik (academic Skill), keterampilan sosial (social skill) dan interpersonal skill.

Hammoud dan Ratzki (2008:62) berpendapat bahwa pembelajaran kooperatif merupakan sebuah interaksi dalam pembelajaran kelompok yang terikat pada suatu aturan tertentu. Selain itu, Roger, dkk dalam Huda (2014:29) mendefinisikan bahwa pembelajaran kooperatif merupakan pembelajaran kelompok yang berdasarkan perubahan informasi dalam setiap kelompok yang didalamnya setiap pembelajar bertanggung jawab dan dapat meningkatkan pembelajaran anggota yang lain. Dari beberapa definisi yang dikemukakan oleh para ahli, dapat ditarik kesimpulan bahwa pembelajaran kooperatif adalah model pembelajaran yang menempatkan siswa dalam kelompok kecil dengan kemampuan yang berbeda-beda untuk saling membantu dan bekerja sama sehingga dapat mencapai hasil pembelajaran yang maksimal.

Salah satu jenis model pembelajaran koperatif adalah tipe tea party. Menurut Warsono dan Harianto (2017:227) model pembelajaran kooperatif tipe Tea Party merupakan strategi yang mendorong siswa untuk berpikir secara cepat dan siap menjawab pertanyaan guru secara dinamis". Sementara itu Creswell dan Clark dalam Khamidiyah (2018:15) mengatakan tea Party adalah model pembelajaran kooperatif yang dilakukan dengan peserta didik membentuk dua baris saling berhadapan. Kemudian guru memberikan pertanyaan, peserta didik berdiskusi dengan teman di depannya". Berdasarkan beberapa pendapat tersebut, dapat disimpulkan bahwa model pembelajaran Tea Party adalah suatu tipe pembelajaran model Cooperative Learning yang membuat para siswa terlibat dalam aktivitas interaktif dan siap menjawab pertanyaan yang diajukan guru.

Langkah-langkah model pembelajaran kooperatif tipe Tea Party dikemukakan oleh Fathurrohman (2015:95) yaitu siswa membentuk dua barisan dengan siswa saling berhadapan satu sama lain. Guru mengajukan sebuah pertanyaan dan siswa mendiskusikan dengan siswa yang berhadapan dengannya. Setelah satu menit, baris terluar bergerak searah jarum jam sehingga berhadapan dengan pasangan yang baru. Guru mengajukan pertanyaan kedua, dilanjutkan empat atau lima pertanyaan. Model pembelajaran kooperatif tipe Tea Party memiliki beberapa kelebihan dan kekurangan dalam penerapannya, sebagaimana dalam beberapa pendapat, kelebihan model pembelajaran kooperatif tipe Tea Party menurut Warsono dan Hariyanto (2017:227) bahwa "Kelebihan dari model pembelajaran ini adalah mendorong siswa untuk berpikir secara cepat dan siap menjawab pertanyaan yang diajukan guru secara dinamis". Selain itu menurut Fitriani dalam Pebriani, dkk (2016:4) kelebihan model pembelajaran kooperatif tipe Tea Party yaitu dapat meningkatkan pemahaman, berpikir cepat dan memberikan informasi mengenai materi sehingga meningkatkan keaktifan siswa dan hasil belajar.

Berdasarkan beberapa pendapat dapat disimpulkan bahwa kelebihan model pembelajaran kooperatif tipe Tea Party yaitu: (1) mendorong siswa untuk berpikir secara cepat dan siap menjawab pertanyaan yang diajukan guru secara dinamis; (2) adanya struktur yang jelas dan memungkinkan siswa untuk saling berbagi informasi; (3) meningkatkan keaktifan siswa dan hasil belajar bahasa 
Jerman; (4) membuat suasana belajar menyenangkan. Adapun kekurangan model pembelajaran kooperatif tipe Tea Party menurut Woolfolk dalam Khamidiyah (2018:16) yaitu bahwa "Cooperative Learning tipe Tea Party ini membutuhkan pemahaman yang tinggi. Membutuhkan latihan dalam melakukan pembelajaran. Menurut Colorado (2007) "Memerlukan waktu yang lama untuk mempersiapkan pembelajaran dengan baik”. Berdasarkan beberapa pendapat dapat disimpulkan bahwa kekurangan model pembelajaran kooperatif tipe Tea Party yaitu: (1) Memerlukan waktu yang relatif lama untuk mempersiapkan pembelajaran dengan baik; (2) Membutuhkan pemahaman yang tinggi dan membutuhkan latihan dalam melakukan pembelajaran menggunakan Tea Party.

\section{METODE PENELITIAN}

Penelitian ini merupakan penelitian eksperimen dan bertujuan untuk mengetahui pengaruh yang ditimbulkan dari sebuah perlakuan (treatment). Dalam penelitian ini terdapat 2 variabel, yaitu variabel bebas $(X)$ dan variabel terikat $(Y)$. Variabel bebas $(X)$ adalah model pembelajaran Tea Party dan variabel terikatnya $(\mathrm{Y})$ adalah keterampilan berbicara bahasa Jerman siswa kelas XI IPS SMAN 1 Kabupaten Bone. Desain penelitian yang digunakan adalah true eksperiment dengan bentuk Pre-test Post-test Control Group Design. Teknik pengumpulan data dalam penelitian ini menggunakan instrumen tes. Tes dalam penelitian ini dilakukan sebanyak dua kali, yaitu pre-test dan post-test. Pre-test dilakukan untuk mengetahui kemampuan awal berbicara bahasa Jerman siswa kelas XI IPS SMAN 1 Kabupaten Bone. Setelah dilaksanakan tes awal, langkah selanjutnya yaitu pemberian treatment pada kelas eksperimen dengsn model pembelajaran Tea Party dan menggunakan model pembelajaran konvensional pada kelas kontrol. Post-test adalah tes yang diberikan setelah perlakuan selesai diterapkan.

Tujuan dari tes ini adalah untuk mengetahui perbedaan yang signifikan antara prestasi belajar keterampilan berbicara bahasa Jerman siswa kelas XI IPS SMAN 1 Kabupaten Bone antara yang diajar menggunakan model pembelajaran Tea Party dan yang diajar menggunakan model konvensional. Sampel yang digunakan dalam penelitian ini adalah random sampling yaitu kelas XI IPS 1 sebagai kelas eksperimen dan kelas XI IPS 2 sebagai kelas kontrol. Pembelajaran dilakukan sebanyak 4 kali pertemuan setelah pemberian pre-test pada masing-masing kelas. Pembelajaran pada kedua kelas tersebut dilakukan secara berbeda, siswa pada kelas eksperimen diajar dengan menggunakan model pembelajaran kooperatif tipe Tea Party dan siswa pada kelas kontrol diajar tanpa menggunakan model pembelajaran kooperatif tipe Tea Party.

\section{HASIL DAN PEMBAHASAN}

Pre-test diberikan untuk mengetahui kemampuan awal siswa dalam keterampilan berbicara dan hasilnya menunjukkan bahwa kelas eksperimen (XI IPS 1) memeroleh nilai rata-rata (mean) sebesar 55,71 dengan hasil analisis menunjukkan bahwa 6 siswa $(17,14 \%)$ memeroleh nilai terendah yaitu 42 dan 3 siswa $(8,57 \%)$ yang memeroleh nilai tertinggi yaitu 75. Kelas kontrol (XI IPS 2) memeroleh nilai rata-rata 48,82 dengan hasil analisis menunjukkan bahwa 4 siswa $(11,43 \%)$ memeroleh nilai terendah yaitu 33 dan 3 siswa $(8,57 \%)$ memeroleh nilai tertinggi yaitu 67 . Hasil nilai 
pre-tes tersebut kemudian di uji dengan menggunakan uji normalitas dan uji homogenitas. Uji normalitas untuk mengetahui apakah kedua sampel yang diteliti berdistribusi normal atau tidak. Uji homogenitas untuk mengetahui apakah kedua sampel tersebut homogen atau tidak. Hasil analisis uji normalitas menunjukkan bahwa harga yang diperoleh pada kelas eksperimen (XI IPS 1) dan kelas kontrol (XI IPS 2) masing-masing sebesar $-151,35$ dan 153,72. Hasil tersebut kemudian dibandingkan dengan tabel chi-kuadrat ( $\mathrm{dk}=5$, taraf signifikan 0,05$)$ sebesar 11,07 menunjukkan bahwa $\quad \chi_{\text {hitung }}^{2}(-151,35)<\chi_{\text {tabel }}^{2}(11,07)$ dan $\chi_{\text {hitung }}^{2}(-153,72)<$ $\chi_{\text {tabel }}^{2}(11,07)$. Berdasarkan hal tersebut distribusi pretest kelas eksperimen dan kelas kontrol dinyatakan normal. Artinya tes yang diberikan sesuai dengan kemampuan siswa. Adapun hasil uji homogenitas menunjukkan bahwa nilai $\mathrm{F}_{\text {hitung }}$ pada kelas eksperimen dan kelas kontrol adalah 1,02. Hasil tersebut dibandingkan dengan $\mathrm{F}_{\text {tabel }}$ ( $d k=5$, taraf signifikan 0,05) sebesar 5,050. Hal ini menunjukkan bahwa $F_{\text {hitung }}$ lebih kecil dari $F_{\text {tabel }}(1,02<5,050)$. Hal ini berarti bahwa kelompok data pada kelas eksperimen dan kontrol dinyatakan homogen.

Pemberian treatment pada kelas eksperimen dengan model pembelajaran kooperatif tipe Tea Party dan pada kelas kontrol menggunakan model pembelajaran konvensional. Setelah 4 kali pertemuan kedua kelas tersebut kembali diberi tes (post-test) keterampilan berbicara bahasa Jerman. Hasil post-test pada kelas eksperimen (XI IPS 1) yang diajar dengan menggunakan model pembelajaran kooperatif tipe Tea Party mengalami peningkatan nilai yang signifikan. Hal ini dapat dilihat dengan perolehan nilai untuk kelas eksperimen, 7 siswa (20\%) memeroleh nilai terendah yaitu 58 yang sebelumnya yaitu 42 dan 3 siswa $(8,57)$ yang memeroleh nilai tertinggi yaitu 92 dengan rata-rata 70,54 yang sebelumnya hanya 55,71. Siswa telah mampu menyampaikan informasi lisan sesuai dengan pertanyaan yang diajukan guru. Terdapat sedikit kesalahan dalam penyusunan kalimat, pelafalan dan pemahaman namun isi teks tidak mempengaruhi pemahaman.

Adapun kelas kontrol yang belajar tanpa menggunakan model pembelajaran tidak mengalami peningkatan nilai yang signifikan. Perolehan nilai menunjukkan bahwa 6 siswa (17,14\%) memeroleh nilai terendah yaitu 42 dan 2 siswa (5,71\%) memeroleh nilai tertinggi yaitu 75 Dengan nilai rata-rata 56,23. Tidak seperti pada kelas eksperimen, informasi yang disampaikan oleh siswa terdapat beberapa kesalahan, baik struktur kalimat yang mempengaruhi pemahaman, cara pelafalan dan pemahaman isi percakapan. Selanjutnya, dilakukan pengujian hipotesis dengan menggunakan uji-t untuk mengetahui hasil akhir dari penelitian ini, yaitu ada tidaknya perbedaan tingkat keterampilan berbicara bahasa Jerman pada hasil postes kelas eksperimen dan kelas kontrol. Hasil penghitungan tersebut diperoleh data bahwa $t_{\text {hitung }}$ sebesar 6,141 . Setelah dibandingkan dengan $t_{\text {tabel }}$ pada taraf signifikansi 0,05 dan dk 68 sebesar 1,998 maka dapat disimpulkan bahwa t-hitung ( $t_{\text {hitung }}$ ) lebih besar daripada $t$-tabel $\left(t_{\text {tabel }}\right)$ yakni $t_{\text {hitung }}(6,141)>t_{\text {tabel }}(1,998)$. Dengan demikian $\mathrm{H}_{1}$ yang berbunyi Model pembelajaran kooperatif tipe Tea Party efektif dalam keterampilan berbicara bahasa Jerman siswa kelas XI IPS SMAN 1 Kabupaten Bone diterima dan $\mathrm{H}_{\mathrm{o}}$ yang berbunyi: Model pembelajaran kooperatif tipe Tea Party tidak efektif dalam keterampilan berbicara bahasa Jerman siswa kelas XI IPS SMAN 1 Kabupaten Bone ditolak. 


\section{KESIMPULAN}

Berdasarkan hasil analisis data, pengajuan hipotesis dan pembahasan dapat disimpulkan bahwa model pembelajaran kooperatif tipe Tea Party efektif dalam pembelajaran keterampilan berbicara bahasa Jerman siswa kelas XI IPS SMAN 1 Kabupaten Bone. Hal ini dapat dilihat dari hasil perhitungan uji-t terhadap nilai posttest siswa. Adapun hasil analisis uji-t yaitu, $t_{\text {hitung }}=6,141>t_{\text {tabel }}=1,998$ pada taraf signifikansi 0,05. Pembuktian ini menunjukkan bahwa Model pembelajaran kooperatif tipe Tea Party efektif dalam keterampilan berbicara bahasa Jerman siswa kelas XI IPS SMAN 1 Kabupaten Bone.

\section{DAFTAR PUSTAKA}

Colorado, C. (2007). Cooperative learning strategy. Diakses di http://www. colorincolorado.org/educators/content/cooperative/

Fathurrohman, Muhammad. (2015). Model-model Pembelajaran Inovatif. Yogyakarta: Ar-Ruzz Media.

Hammoud, Antje, dan Ratzki, Anne. (2008). Was ist Kooperatives Lernen. SV Reichersdorf/Konstantin Wolff: Goethe Institut.

Huda, Miftahul. (2014). Cooperative Learning Metode, Teknik, Struktur dan Model Penerapan. Yogyakarta: Pustaka Pelajar.

Khamidiyah, Izzah Riyatna. (2018). Penerapan Cooperative Learning Tipe Tea Party Untuk Meningkatkan Keterampilan Menemukanlde Pokok Paragraf Pada Mata Pelajaran Bahasa indonesia Di Kelas Iv Mi Bina Bangsa Krembangan Surabaya. Skripsi: Universitas Islam Negeri Sunan Ampel Surabaya. Diakses di http://digilib.uinsby.ac.id/22632/2/Izzah\%20Riyatna\%20Khamidiyah_D0721400 6.pdf pada tanggal 20 Februari 2018 pukul 10.00 WITA

Pebriani, Vina dkk. (2016). Penerapan Model Pembelajaran Kooperatif Tipe Tea Party Untuk Meningkatkan Penguasaan Kosakata Bahasa Jepang Siswa Kelas X SMA Bpi 1 Bandung. Bandung: Jurnal. Universitas Pendidikan Indonesia.

Riyanto, Yatim. (2009). Paradigma Baru Pembelajaran: Sebagai Referensi bagi Pendidik dalam Implementasi Pembelajaran yang Efektif dan Berkualitas. Jakarta: Kencana.

Warsono dan Hariyanto. (2017). Pembelajaran Aktif: Teori dan Asesmen. Bandung: PT Remaja Rosdakarya. 